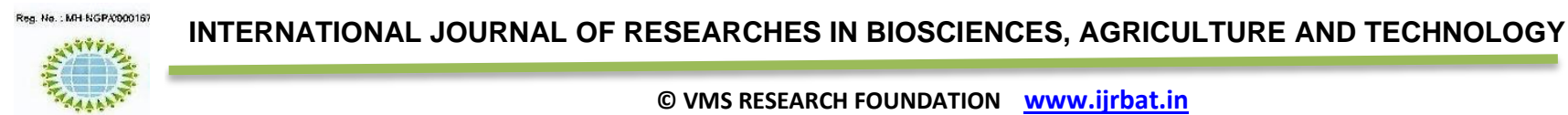

\title{
GLOBAL CLIMATE CHANGE \& AGRICULTURAL TECHNOLOGIES: A GEOGRAPHICAL PERSPECTIVE
}

\author{
1R. E. Najan and *2A. S. Darandale \\ ${ }^{1}$ New Arts, Commerce and Science College, Parner Tal. Parner, Dist. Ahmednagar \\ ${ }^{* 2}$ Arts, Commerce and Science College, Sonai, Tal. Newasa, Dist. Ahmednagar \\ *Email: amoldarandale87@gmail.com
}

Communicated: 30.07 .20

Published: 30.09 .2020

\begin{abstract}
Climate change is one of the inescapable global issues of today. Climate change and agriculture are interrelated processes, both of which take place on a global scale. Global warming affects Agriculture in a number of ways, including through changes in average temperatures, rainfall, and climate extremes (e.g., heat waves, cyclones); changes in pests and crop diseases; changes in atmospheric carbon dioxide; changes in the nutritional quality of some foods; and changes in sea level. Agriculture is an important sector of the Indian economy. Indian agriculture sector accounts for 18 per cent of India's gross domestic product (GDP) and provides employment to $50 \%$ of the countries workforce. India remains among main three as far as production of different agricultural things like paddy, wheat, pulses, groundnut, rapeseeds, natural products, vegetables, sugarcane, tea, jute, cotton, tobacco leaves and so on. The article addresses adoption of agricultural technologies to cope with climate change such as biotechnology (HYV), farm ponds, watershed management, improved irrigation techniques, chemical fertilizers, farm machineries, organic farming, weather forecasting system, drone technology, RS \& GIS, infrastructure development storage facilities, poly houses, shed net, vertical farming, hydroponics and so on.
\end{abstract}

Key words: Climate, Technology, Crops, Production, Global Warming.

\section{INTRODUCTION:}

Agriculture is a primary source of food $\&$ it is an important sector of the Indian economy. Today climate change has become a cross cutting issue. Agriculture industry has been adversely getting affected by climate change. Agricultural technologies can play a crucial role in addressing these fundamental challenges. Several agricultural technologies could help farmers to coping with climate change such as biotechnology, watershed management, farm ponds, improved irrigation techniques, farm machineries, organic farming, accurate weather forecasting, drone technology, poly houses etc. Adoption \& proper implementation of such technologies could help farmers for agricultural development.

\section{OBJECTIVES:}

i)

ii)

iv)
To observe how the climate changed $\&$ its impact on agriculture activity.

To utilize new technologies with respect to climate change.

To find out efficiency of new technology in agriculture practices.

To explore merits \& demerits of these technologies.

\section{Hypothesis:}

i) There is a positive impact of technology on agriculture with respect to climate change.

ii) Agriculture technology has merits \& demerits. 


\section{CLIMATIC CHANGE \& ITS IMPACT ON AGRICULTURE:}

The climate is long term and average condition of the Earth's atmosphere regarding atmospheric elements. The climatic elements like as temperature, precipitation, humidity etc. The type of climate we experience now might be prevailing over the last 10,000 years with minor and occasionally wide fluctuations. The planet earth has witnessed many variations in climate since the beginning. The rings in the trees provide clues about wet and dry periods. Historical records describe the vagaries in climate. All these evidences indicate that change in climate is a natural and continuous process. India also witnessed alternate wet and dry periods. Earth's climate has been changed lot of times. According to experts major cause of climate change is global warming.

Global warming has adverse effects on the agriculture, biodiversity, human health, forests and so on. After the 1950, the issue of global warming is rise up. Green House Effect is the major cause of global warming and $\mathrm{GHG}_{\mathrm{s}}$ like $\mathrm{CO}_{2}, \mathrm{CH}_{4}, \mathrm{NOx}$, etc. are responsible for it. The human activities like industrialization, deforestation, urbanization, transportation etc..are intensifying it. Let us hope the world community responds to this challenge and adopts a lifestyle that leaves behind livable world for the generations to come.

Higher $\mathrm{CO}_{2}$ levels can affect crop yields. Some laboratory experiments suggest that elevated $\mathrm{CO}_{2}$ levels can increase plant growth. However, other factors, such as changing temperatures, ozone, and water and nutrient constraints, may counteract these potential increases in yield. For example, if temperature exceeds a crop's optimal level, if sufficient water and nutrients are not available, yield increases may be reduced or reversed. Elevated $\mathrm{CO}_{2}$ has been associated with reduced protein and nitrogen content in alfalfa and soybean plants, resulting in a loss of quality. Reduced grain and forage quality can reduce the ability of pasture and rangeland to support grazing livestock.

More extreme temperature and precipitation can prevent crops from growing. Extreme events, especially floods and droughts, can harm crops and reduce yields.

For example The widespread floods in Sangli, Kolhapur and Satara districts are expected to cause huge losses to the agricultural sector in the region. As per initial estimates, livestock by the thousands and cropping area of around 1.5 lakh hectare has been lost in the floods. The 2013 drought in Maharashtra in India came about after the region received lower rainfall during the monsoon season June to September 2012. It is considered as the region's worst drought in 40 years. The worst-hit areas in Maharashtra were Solapur, Parbhani, Ahmednagar, Latur, Pune, Satara, Beed and Nashik.

Nitrous oxide, a powerful greenhouse gas produced by soil cultivation practices, especially the use of commercial and organic fertilizers, fossil fuel combustion, nitric acid production, and biomass burning

\section{Agricultural Technologies:}

Modern farms and agricultural operations work far differently than those a few decades ago, primarily because of advancements in technology, including sensors, devices, machines, and information technology. Today's agriculture routinely uses sophisticated technologies such as robots, temperature and moisture sensors, aerial images, and GPS technology. These advanced devices and precision agriculture and robotic systems allow businesses to be more profitable, 
efficient, safer, and more environmentally friendly.

Farmers no longer have to apply water, fertilizers, and pesticides uniformly across entire fields. Instead, they can use the minimum quantities required and target very specific areas, or even treat individual plants differently. Benefits include:

- Higher crop productivity

- Decreased use of water, fertilizer, and pesticides, which in turn keeps food prices down

- Reduced impact on natural ecosystems

- Less runoff of chemicals into rivers and groundwater

- Increased worker safety

Agricultural biotechnology, also known as agritech, is an area of agricultural science involving the use of scientific tools and techniques, including genetic

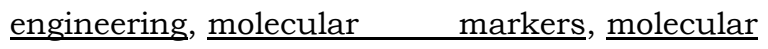
$\underline{\text { diagnostics, vaccines, }}$ and tissue culture, to modify living organisms: plants, animals, and microorganisms. Crop biotechnology is one aspect of agricultural biotechnology which has been greatly developed upon in recent times. Desired trait is exported from a particular species of Crop to an entirely different species. These transgene crops possess desirable characteristics in terms of flavor, colour of flowers, growth rate, size of harvested products and resistance to diseases and pests.

The main aim of watershed management is to conserve the soil, plant, and water resources of a catchment while benefiting humanity. The watershed management implies, the judicious use of all the resources i.e. land, water, vegetation in an area for providing an answer to alleviate drought, moderate floods, prevent soil erosion, improve water availability and increase food, fodder, fuel and fiber on sustained basis. Watershed to achieve maximum production with minimum hazard to the natural resources and for the well-being of people. The management should be carried out on the watershed basis.

Improving irrigation efficiency aims at minimizing water use within the agricultural sector while continuing to maintain optimal crop productivity rates. Water (and energy) efficient irrigation also provides a number of environmental and socio-economic benefits. High irrigation efficiency is becoming increasingly important due to the current decrease in available water resources and growing populations that drive expansion of agricultural activities.

One alternative form of agriculture that is much more sustainable for urban environments is hydroponics. Hydroponic agriculture involves growing plants in nutrient-rich water that can be recycled, all with minimal use of soil.

The rise of digital agriculture and its related technologies has opened a wealth of new data opportunities. Remote sensors, satellites, and UAVs can gather information 24 hours per day over an entire field. These can monitor plant health, soil condition, temperature, humidity, etc. The amount of data these sensors can generate is overwhelming, and the significance of the numbers is hidden in the avalanche of that data.

\section{CONCLUSION:}

Though climate change has become a major obstacle in the agriculture sector from the last few decades. It basically has been affecting global average temperature increase, rainfall irregularity \& uncertainty, climatic extreme events, etc. These all elements, in turn, has an adverse effect on the agriculture industry. But with the help of modern technologies, farmers could able to tackle \& manage the agricultural practices such as watershed management program, biotechnology, hydroponics, use of 
chemical fertilizers \& insecticides, GIS and Remote sensing techniques enable farmers to cope with climate change. That's why the role of technology had been helpful in the sector but at the same time, it is necessary to protect \& conserve natural resources.

\section{REFERENCES:}

Shafi, M., 2006: Agricultural Geography, Doring Kindersley India Pvt. Ltd., New Delhi

Singh, J., and Dhillon, S.S., 1984: Agricultural Geography, Tata McGraw Hill, New Delhi.

Hussain, M. (1978): Agricultural Geography, Rawat Publication, Jaipur

https://en.wikipedia.org/wiki/Climate_change_ and_agriculture https://allianceforscience.cornell.edu/blog/201 8/04/agricultural-technology-canhelp-curtail-climate-change/

http://www.fao.org/3/CA3204EN/ca3204en.pd $\mathrm{f}$

https://www.researchgate.net/publication/228 445877_Agricultural_technologies_for_ climate_change_in_developing_countri es_Policy_options_for_innovation_and_ technology_diffusion

https://www.sciencedirect.com/science/article/ pii/S037837741400211X 